\title{
New postcranial remains of large toxodontian notoungulates from the late Oligocene of Mendoza, Argentina and their systematic implications
}

\author{
Santiago Hernández Del Pino, Federico D. Seoane, and Esperanza Cerdeño \\ Acta Palaeontologica Polonica 62 (1), 2017: 195-210 doi:https://doi.org/10.4202/app.00301.2016
}

During the last decade, the Deseadan (late Oligocene) Quebrada Fiera locality, Mendoza Province, Argentina, has provided a large amount of mammal remains. Taxonomic studies have shown the presence of faunal elements common with other Deseadan associations from Patagonia and lower latitudes (Salla, Bolivia), as well as endemic taxa of different groups of mammals (Notohippidae, Leontiniidae, Homalodotheriidae, Hegetotheriidae, and Metatheria) and even a gastropod. In this work, we present a taxonomic and phylogenetic analysis of a set of postcranial fossils of three families of the suborder Toxodontia (Notoungulata). The postcranial elements are assigned to taxa previously recognized at Quebrada Fiera, such as the leontiniid Gualta cuyana and the homalodotheriid Asmodeus petrasnerus, but also to the family Toxodontidae that is represented by Proadinotherium sp. and another larger toxodontid; a few dental remains of Proadinotherium are also included as this is the first time that toxodontids from Quebrada Fiera are described. In the case of A. petrasnerus, an almost complete calcaneum allows us to expand the diagnosis of this taxon. The bones assigned to G. cuyana enlarge the anatomical knowledge of this species. In turn, the presence of the genus Proadinotherium extends its geographic distribution in Argentina and adds to the extra-Patagonian record of $P$. saltoni from Salla, Bolivia. Phylogenetic results do not differ much from previous analyses using postcranial characters, and the obtained consensus trees show low node supports. The various phylogenetic analyses performed here provide a more robust framework to interpret the relationships of the studied taxa.

Key words: Mammalia, Toxodontidae, Leontiniidae, Homalodotheriidae, postcranium, Deseadan Age, Argentina, Mendoza.

Santiago Hernández Del Pino [stgo86@gmail.com] and Esperanza Cerdeño [espe@mendoza-conicet.gob.ar], Paleontología, Instituto de Nivología, Glaciología y Ciencias Ambientales, Centro Científico Tecnológico-CONICET-Mendoza. Avda, Ruiz Leal s/n, 5500 Mendoza, Argentina. Federico D. Seoane [seoane.federico@gmail.com], Universidad de Buenos Aires, CONICET, Instituto de Estudios Andinos Don Pablo Groeber (IDEAN), Facultad de Ciencias Exactas y Naturales, Ricardo Güiraldes 2160, C1428EGA Buenos Aires, Argentina. 
This is an open-access article distributed under the terms of the Creative Commons

Attribution License (for details please see creativecommons.org), which permits unrestricted use, distribution, and reproduction in any medium, provided the original author and source are credited.

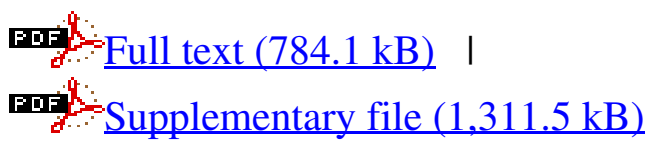

